\title{
KOMUNIKASI ANTARA ULAMA DAYAH DAN KEPOLISIAN DALAM MENANGGULANGI KEMUNGKARAN DI KABUPATEN ACEH TIMUR
}

\author{
Baihaki \\ Sekolah Tinggi Agama Islam Dayah Amal Peureulak \\ Teukubaihaki2@gmail.com
}

\begin{abstract}
Abstrak
Komunikasi merupakan proses penyampaian pesan dari komunikator ke kekomunikan sehingga terjadinya komunikasi yang efektif, baik secara bahasa maupun bukan bahasa. Namun fenomena komunikasi yang terjadi antara ulama dayah dengan kepolisian Kabupaten Aceh Timur selama ini terkesan masih kurang efektif. Karena itu penelitian ini dilakukan dengan tujuan untuk mendiskripsikan bentuk komunikasi yang terjadi antara ulama dayah dengan kepolisian dalam menaggulagi kemungkaran di Aceh Timur.

Penelitian ini mengunakan pendekatan kualitatif dengan teknik pengumpulan data yaitu observasi, wawancara dan dokumentasi. Untuk analisis data merujuk pada pola yang dikembangkan oleh Lexy J Moleong dengan tahapan-tahapan analisis yang dimulai dari mengumpul data, reduktif data, display data dan verifikasi data. Untuk memudahkan proses pengumpulan data dan analisis data maka disusun beberapa pertanyaan penelitian sebagai berikut : 1) Apa saja jenis kemungkaran yang sering terjadi di wilayah Kabupaten Aceh Timur, 2) Bagaimana bentuk komunikasi antara ulama dayah dengan lembaga kepolisian dalam menanggulangi kemungkaran di Kabupaten Aceh Timur, 3) Bagaimana peluang dan tantangan berkomunikasi antara ulama dengan kepolisian dalam menanggulangi kemungkaran di Kabupaten Aceh Timur.

Hasil penelitian menunjukkan bahwa kerja sama antara ulama dayah dengan kepolisian dalam menaggulangi kemungkaran seperti pencurian, narkoba dan aliran sesat dilakukan dalam bentuk sosialisasi dan mediasi, adapun peluang yang dihadapi oleh ulama dayah dengan kepolisian adalah saling koordinasi dan saling mempercayai, sedangkan tatangannya adalah sedikit waktu untuk saling bertatap muka serta kurangnya dukungan dari masyarakat.
\end{abstract}

Kata Kunci: Komunikasi, Ulama Dayah, Kepolisian, Kemungkaran

\section{A. Pendahuluan}

Komunikasi adalah suatu proses penyampaian pesan, baik dengan lambang, bahasa maupun dengan isyarat. Dengan kata lain, jika lambangnya tidak dimengerti oleh salah satu 
pihak, maka komunikasinya akan tidak lancar dan tidak komunikatif. Tidak efektifnya proses komunikasi disebabkan oleh 3 hal pokok unsur utama komunikasi yaitu komunikator, isi pesan, dan juga komunikan. Komunikasi sebagai ilmu pengetahuan sosial yang bersifat multidisipliner, tidak bisa menghindari perspektif dari beberapa ahli yang tertarik pada kajian komunikasi, sehingga definisi dan pengertian komunikasi menjadi semakin banyak dan beragam. Masing-masing mempunyai penekanan arti, cakupan, konteks yang berbeda satu sama lain, tetapi pada dasarnya saling melengkapi dan menyempurnakan makna komunikasi sejalan dengan perkembangan ilmu komunikasi. ( Arifin, $2006: 1$ )

1. Tujuan dan fungsi Komunikasi

Komunikasi memiliki beberapa tujuan antara lain sebagai berikut :

- Supaya yang disampaikan komunikator dapat dimengerti oleh komunikan. Agar dapat dimengerti oleh komunikan maka komunikator perlu menjelaskan pesan utama dengan sejelas-jelasnya dan sedetail mungkin.

- Agar dapat memahami orang lain. Dengan melakukan komunikasi, setiap individu dapat memahami individu yang lain dengan kemampuan mendengar apa yang dibicarakan orang lain.

- Agar pendapat kita diterima orang lain. Komunikasi dan pendekatan persuasif merupakan cara agar gagasan kita diterima oleh orang lain.

- Menggerakkan orang lain untuk melakukan sesuatu. Komunikasi dan pendekatan persuasif kita mampu membangun persamaan presepsi dengan orang kemudian menggerakkannya sesuai keinginan kita

Secara umum fungsi komunikasi adalah sebagai berikut.

- Sebagai Kendali : Fungsi komunikasi sebagai kendali memiliki arti bahwa komunikasi bertindak untuk mengendalikan perilaku orang lain atau anggota dalam beberapa cara yang harus dipatuhi.

- Sebagai Motivasi : Komunikasi memberikan perkembangan dalam memotivasi dengan memberikan penjelasan dalam hal-hal dalam kehidupan kita.

- Sebagai Pengungkapan Emosional : Komunikasi memiliki peranan dalam mengungkapkan perasaan-perasaan kepada orang lain, baik itu senang, gembira, kecewa, tidak suka. dan lain-lainnya.

- Sebagai Informasi : Komunikasi memberikan informasi yang diperlukan dari setiap individu dan kelompok dalam mengambil keputusan dengan meneruskan data guna mengenai dan menilai pemilihan alternatif. .( Effendi, $2003: 27)$

2. Lingkungan komunikasi

Lingkungan (konteks) komunikasi setidaknya memiliki beberapa dimensi:

a. Fisik, adalah ruang dimana komunikasi berlangsung secara nyata atau berwujud.

b. Sosial-psikoilogis, meliputi misalnya tata hubungan status di antara mereka yang terlibat, peran yang dijalankan orang, serta aturan budaya masyarakat di 
mana mereka berkomunikasi. Lingkungan atau konteks ini juga mencakup rasa persahabatan atau permusuhan, formalitas atau informalitas, serius atau senda gurau.

c. Temporal (waktu), mencakup waktu dalam hitungan jam, hari, atau sejarah dimana komunikasi berlangsung.

\section{B. Bentuk-Bentuk Komunikasi}

Sebagaimana telah diketahui, manusia hidup saling membutuhkan antara satu dengan yang lain. Manusia tidak dapat hidup sendiri secara individualis, akan tetapi mereka mempunyai jiwa sosial. Dan untuk itu mereka harus menggunakan komunikasi. Komunikasi antara satu dengan yang lain terjadi dalam beberapa bentuk antara lain :

\section{Komunikasi intrapersonal}

Komunikasi intrapersonal sering disebut juga komunikasi intrapribadi, secara harfiah dapat diartikan sebagai komunikasi dengan diri sendiri. Komunikasi yang terjadi dalam diri individu ini juga berfungsi untuk mengembangkan kreatifitas imajinasi, memahami dan mengendalikan diri serta meningkatkan kematangan berfikir sebelum mengambil suatu keputusan dan komunikasi ini akan menjadikan seseorang agar tetap sadar akan kejadian disekitarnya. Komunikasi ini merupakan landasan komunikasi antar pribadi dan komunikasi dalam konteks-konteks lainnya, meskipun dalam disiplin komunikasi tidak dibahas secara rinci dan tuntas. Dengan kata lain, komunikasi intrapribadi ini inheren dalam komunikasi dua orang, tiga orang, dan seterusnya, karena sebelum berkomunikasi dengan orang lain kita biasanya berkomunkasi dengan diri sendiri (mempersepsi dan memastikan makna pesan orang lain), hanya saja caranya tidak disadari. Keberhasilan komunikasi kita dengan orang lain bergantung pada keefektifan komunikasi kita dengan diri sendiri.

\section{Komunikasi organisasi}

Komunikasi organisasi terjadi dalam suatu organisasi, bersifat formal dan juga informal, dan berlangsung dalam suatu jaringan yang lebih besar dari pada komunikasi kelompok. Komunikasi organisasi seringkali juga melibatkan komunikasi secara sosialisasi dan mediasi. Komunikasi formal adalah komunikasi menurut struktur organisasi, yakni komuniksi kebawah, komunikasi keatas, dan komuniksi horizontal, sedangkan kamunikasi informal tidak tergantung pada struktur organisasi, seperti komunikasi antar sejawat, juga termasuk gossip.( Mulyana, $2010: 131$ ) 


\section{Komunikasi Kelompok}

Kelompok adalah sekumpulan manusia yang mempunyai tujuan bersama, yang berinteraksi satu sama lain untuk mencapai tujuan bersama, mengenal satu sama lainnya, dan memandang mereka sebagai bagian dari kelompok tersebut. Kelompok ini misalnya adalah kelompok diskusi, kelompok pemecahan masalah,. Dengan demikian, komunikasi kelompok biasanya merujuk pada komunikasi yang dilakukan kelompok tersebut. Komunikasi kelompok dengan sendirinya melibatkan juga komunikasi antar pribadi, karena itu kebanyakan teori komunikasi antar pribadi berlaku juga bagi komunikasi kelompok. Dengan kata lain komunikasi kelompok ialah interaksi tatap muka antara tiga orang atau lebih dengan tujuan berbagi informasi, pemecahan masalah yang mana anggotanya dapat mengingat karakteristik pribadi anggota lain secara tepat. Sedangkan menurut Goldberg, komunikasi kelompok ialah suatu bidang studi, penelitian dan penerapan yang menitikberatkan tidak hanya pada proses kelompok secara umum, tetapi juga pada perilaku komunikasi individu untuk memiliki susunan rencana tertentu untuk mencapai tujuan kelompok.Media komunikasi kelompok ini ialah seperti Seminar dengan tujuan membicarakan suatu masalah dengan menampilkan pembicara kemudian meminta pendapat.

\section{Komunikasi Massa}

Komunikasi massa adalah komunikasi yang menggunakan media massa, baik cetak(surat kabar, majalah) atau elektronik (radio, televisi), yang dikelola oleh suatu lembaga atau orang yang dilembagakan, yang ditujukan kepada sejumlah besar orang yang tersebar dibanyak tempat. Pesan-pesannya bersifat umum, disampaikan secara cepat, serentak dan selintas (khususnya media elektronik). Komunikasi antarpribadi, komunikasi kelompok dan komunikasi organisasi berlangsung juga dalam proses untuk mempersiapkan pesan yang disampaikan media massa ini.

Defleur dan Mcquails mendefinsikan komunikasi massa sebagai "suatu proses melalui mana komunikator-komunikator menggunakan media untuk menyebarluaskan pesan-pesan secara luas dan terus-menerus menciptakan makna-makna serta diharapkan dapat mempengaruhi khalayak yang besar dan beragam dengan melalui berbagai macam cara." Definisi lain datang dari Littlejohn yang mengatakan "komunikasi massa adalah suatu proses dengan mana organisasi-organisasi media memproduksi dan mentransmisikan pesan-pesan kepada publik yang besar, dan proses di mana pesan-pesan itu dicari, digunakan, dimengerti, 
dan dipengaruhi oleh audien." Ini artinya, proses produksi dan transmisi pesan dalam komunikasi massa sangat dipengaruhi oleh kebutuhan dan kepentingan.

\section{Fungsi Dan Tujuan Komunikasi}

Komunikasi mempunyai dua fungsi. Pertama, fungsi social, yakni untuk tujuan kesenangan, untuk menunjukan ikatan dengan orang lain, membangun dan memelihara hubungan. Kedua, fungsi pengambilan keputusan, yakni memutuskan untuk melakukan atau tidak melakukan sesuatu pada saat tertentu.

Fungsi komunikasi menurut Onong Uchiana Effendi dalam buku nyan yang berjudul Ilmu teori dan falsafat komunikasi mempunyai pendapat sebagai berikut :
a. Memberikan informasi
b. Mendidik masyarakat
c. Mempengaruhi masyarakat
d. menghibur masyarakat

Tujuan Komunikasi upaya komunikasi yang dilakukan tentunya mempunyai tujuan tertentu, tujuan yang dimaksud disini menunjuk pada hasil atau akibat pelaku komunikasi. Tujuan komunikasi dapat dilihat dari perspektif yaitu kepentingan sumber/pengirim/komunikator kepentingan pertama / komunikan dengan demikian dapat dijelaskan sebagai berikut:.

a. Memberikan informasi kita sebagai komunikator memberikan informasi dan berperan aktif dalam menjelaskan kepada komunikan / penerima dengan sebaik-baiknya dan sehingga mereka dapat mengerti apa yang kita maksudkan.

b. Mendidik menggerakkan orang lain untuk melakukan sesuatu, menggerakkan sesuatu itu dapat bermacam-macam, mungkin berupa kegiatan, kegiatan yang dimaksud disini adalah kegiatan yang lebih banyak mendorong, namun yang harus diingat adalah bagaimana cara yang baik untuk melakukannya.

c. Menyenangkan/menghibur peran komunikator adalah memahami orang lain, kita sebagai komunikator harus mengerti benar aspirasi masyarakat tentang apa yang diinginkan, jangan menginginkan kemauannya. ( Mulyana, $2010: 140$ ) 


\section{Kerangka Teori}

Sebelum melakukan penelitian, seorang peneliti perlu menyusun suatu kerangka teori sebagai landasan berpikir yang menunjukkan dari sudut mana peneliti menyoroti masalah yang diteliti. Kemudian kerangka teori ini digunakan sebagai landasan atau dasar pemikiran dalam penelitian yang dilakukan.

Komunikasi Antara Ulama Dayah dan Kepolisian dalam Menanggulangi Kemungkaran di Kabupaten Aceh Timur dapat digunakan dalam kerangka berikut:
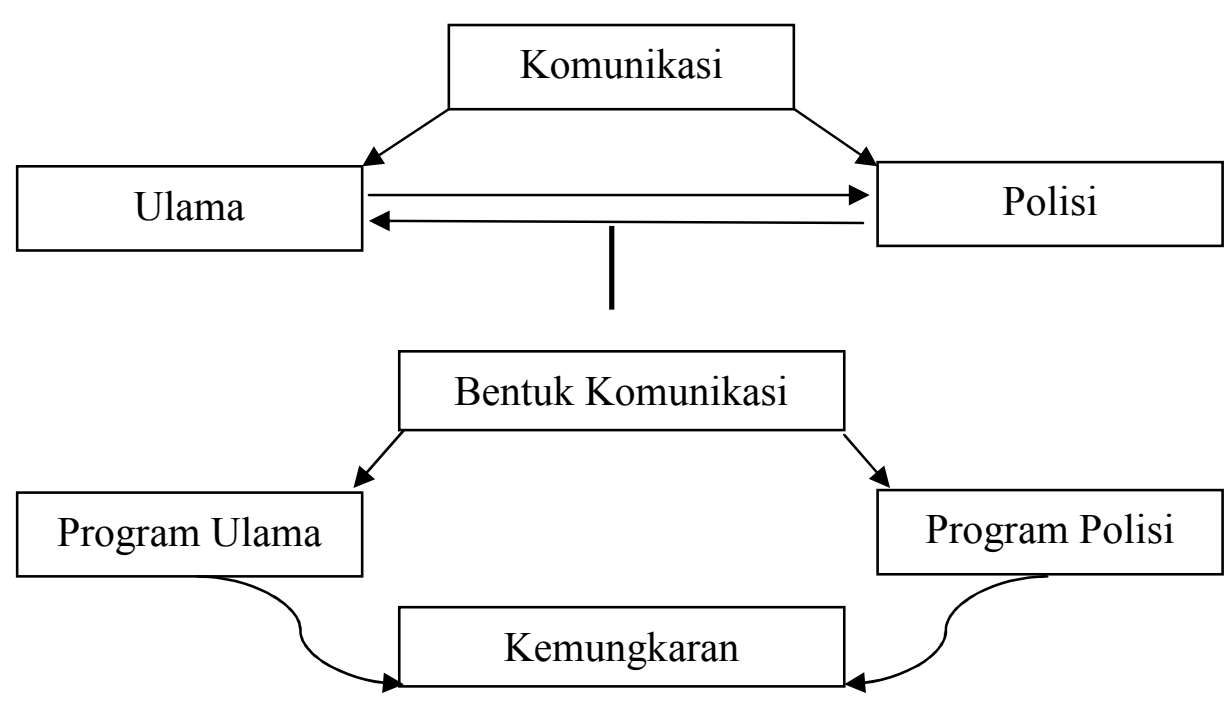

\section{E. Metode Penelitian}

Penelitian ini menggunakan metode deskriptif, dalam hal ini termasuk ke dalam penelitian kualitatif yaitu didefinisikan sebagai prosedur penelitian dan menghasilkan data deskriptif berupa kata-kata tertulis dari perilaku yang diamati. Sedangkan jenis data dalam penelitian ini adalah data primer yang penulis peroleh dari observasi dan wawancara terstruktur terhadap informan yang mempunyai relevansi dengan penelitian ini. Metode analisis data yang digunakan dalam penelitian ini adalah model analisis interaktif (interactive model of analysis) yang meliputi tiga tahapan, yaitu reduksi data, penyajian data, dan penyimpulan data. 


\section{F. Hasil Penelitian Dan Analisis}

1. Jenis-jenis kemungkaran di Kabupaten Aceh Timur

Mengajak kepada kebaikan dan mencegah kemungkaran merupakan ciri utama masyarakat orang-orang yang beriman, setiap kali Al-qur'an memaparkan ayat yang berisi sifat-sifat orang-orang beriman yang benar dan menjelaskan risalahnya dalam kehidupan ini, kecuali ada perintah yang jelas,atau anjuran dan dorongan bagi orang-orang beriman untuk mengajak kepada kebaikan dan mencegah kemungkaran, maka tidak heran jika masyarakat muslim menjadi masyarakat yang mengajak kepada kebaikan dan mencegah kemungkaran karena kebaikan negara dan rakyat tidak sempurna kecuali dengannya.

Perbuatan yang termasuk kemungkaran atau tindakan kriminal kejahatan yang ada di polres Aceh Timur (Sumber Data 2015) antara lain:
a. Pencurian
b. Perdagangan dan penyalahgunaan narkotika.
c. Korupsi, penyogokan, penyuapan.
d. Aliran sesat
e. Penggunaan senjata api pelanggaran sumpah.
f. Bigami yaitu kawin rangkap satu saat
g. Kejahatan-kejahatan politik.
h. Penculikan.

2. Bentuk-Bentuk Komunikasi Antara Ulama Dayah Dengan Kepolisian Di Kabupaten Aceh Timur

Ulama dan umara adalah pasangan pemuka masyarakat yang utama. Ulama merupakan kosakata bahasa Arab, bentuk jamak dari kata alim. Artinya orang yang berpengetahuan, ahli ilmu, orang pandai. Dalam bahasa Indonesia menjadi bentuk tunggal orang yang ahli ilmu agama Islam. Kata ulama sepadan dengan ulul albab dalam Al-qur'an yaitu orang yang arif. Umara merupakan bentuk jamak dari kata amir artinya pemimpin, penguasa. Kosakata amir sepadan dengan ulul amri dalam Al-qur'an yang artinya orang yang mempunyai pengaruh, kekuasaan orang yang memangku urusan rakyat penguasa.

Bentuk program kegiatan terjadinya komunikasi ulama dengan kepolisian antara lain:

a. Program Sawe Pesantren

Guna meningkatkan pengetahuan dan pemahaman tentang Kamtibmas, Narkotika, pencurian dan aliran sesat yang dampak negatif kemajuan teknologi informasi kepada santri di dayah polres Aceh Timur melanjutkan program polisi saweu pesantren. Program ini merupakan kunjungan dan sosialisasi langsung ke pesantren. Kapolres Aceh Timur, mengatakan program polisi saweu pesantren merupakan program yang digagas polres Aceh 
Timur. Ini kita selenggarakan atas dasar semangat pengabdian kepada masyarakat dalam rangka mencerdaskan kehidupan bangsa sesuai dengan tugas dan fungsi kelembagaan masing-masing, dalam hal ini antara polres Aceh Timur dan MPU Aceh Timur bekerjasama dalam meningkatkan program ini. Menurut kapolres melalui program tersebut pihaknya menaruh harapan agar polisi terus dekat dengan rakyat. Selain itu, kerjasama dimaksud juga untuk meningkatkan kapasitas institusi dan sumber daya manusia sesuai tugas pokok dan fungsi masing-masing lembaga. Kesepahaman kerja sama Polisi Saweu pesantren ini akan dilaksanakan secara bertahapan di dalam kabupaten Aceh Timur. Sejauh ini dukungan dari pemerintah maupun pesantren sangat bagus. Sehingga program tersebut terus kita lanjutkan bersama-sama. Sehingga ketika adanya kenakalan remaja dapat berubah. Program polisi saweu pesantren selain bertujuan mendekatkan diri polisi dengan masyarakat juga untuk merangkul generasi muda agar bisa terhindar dari hal-hal negatif (Wawancara AKBP Hendri Budiman, S.H,SIK,M.H Selaku Kapolres Aceh Timur pada tanggal 06 Desember 2015).

\section{b. Program pertemuan di Kecamatan.}

Polres Aceh Timur sering juga melakukan sosialisasi keamanan dan ketertiban masyarakat di kecamatan-kecamatan yang ada di Aceh Timur. Sosialisasi ini akan dipimpin langsung oleh Kapolres Aceh Timur AKBP Hendri Budiman. Kapolres menjelaskan, program ini dimaksud untuk mendekatkan diri pada masyarakat. Di samping itu, untuk membawa pesan-pesan kamtibmas, sehingga dengan begitu hubungan masyarakat dan kepolisian makin baik dan bisa saling berkoordinasi dan mediasi. Kita ingin menunjukkan pada masyarakat bahwa polisi itu tidak jahat, polisi itu dekat dengan masyarakat dan polisi itu bagian dari masyarakat. Kapolres Aceh Timur mengatakan, sosialisasi kamtibmas bukan hanya di di kecamatan tapi juga menyambangi desa-desa rawan kriminalitas yang memiliki wilayah yang luas. Maka desa-desa tersebut akan dibagi menjadi dua lokasi dan dua kali pertemuan lanjutnya. Misalnya di sebuah kecamatan terdapat sepuluh desa. Maka di lima desa pertama akan dilaksanakan pertemuan pertama dan lima desa berikutnya pada pertemuan kedua. Kapolres mengharapkan dengan menerapkan pola demikian, pesan-pesan kamtibmas bisa sampai pada masyarakat sehingga ke depan masyarakat bisa lebih komunikatif dan informatif pada kepolisian. Karena kita masih memiliki program yang berkaitan dengan operasi kepolisian. Dalam sosialisasi kamtibmas akan diundang tokohtokoh seperti perangkat pemerintah di tingkat kecamatan maupun desa dan tokoh adat dan ulama-ulama dayah (Wawancara AKBP Hendri Budiman, S.H,SIK,M.H Selaku Kapolres Aceh Timur pada tanggal 06 Desember 2015). 
Bentuk-bentuk komunikasi organisasi yang digunakan ulama dan kepolisian antara lain:

1. Sosialisasi ulama dengan kepolisian dalam bentuk pertemuan di dayah, aula kantor kecamatan yang ada di Kabupaten Aceh Timur dan di aula Kapolres.

2. Mediasi ulama dan kepolisian dengan cara menggunakan alat-alat media untuk saling berkomunikasi dan saling menginformasi agar informasi tersebut bisa mudah didapatkan dan bisa di atasi dengan secepatnya.

Gambar bentuk-bentuk komunikasi organisasi ulama dengan kepolisian :

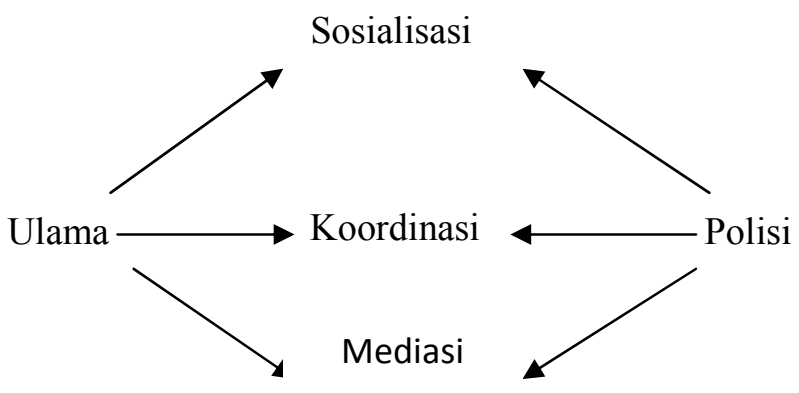

Sebagai pasangan pemuka masyarakat ulama dan umara harus dapat membangun komunikasi yang baik dalam menegakkan amar ma'ruf nahi mungkar. Adapun bentuk komunikasi yang digunakan antara ulama dayah dengan kepolisian dalam menanggulangi kemungkaran adalah komunikasi secara kelompok dengan menerapkan teori fungsional struktural, memprioritaskan prinsip komunikasi tersebut sesuai dengan metode Islam, yaitu prinsip-prinsip komunikasi yang terdapat dalam Al-qur'an.

3. Peluang Dan Tantangan Berkomunikasi Antara Ulama Dengan Kepolisian Dalam Menanggulangi Kemungkaran Di Aceh Timur

Peluang berkomunikasi antara ulama dan polisi sangat terbuka lebar sekali, karena dari masing-mesing pihak mereka tidak ada suatu hambatan pun yang menutupi keduanya untuk berdialog dalam hal mencegah tindak kejahatan/ kemungkaran tersebut. Hal yang selama ini diragukan, berkaitan dengan masa silam Aceh yang sangat menyedihkan karena oknum militer, bukanlah suatu masalah yang menjadikan ulama, khususnya ulama dayah tersebut dengan polisi untuk berkomunikasi dalam menindaklanjuti pencegahan kemungkaran di Kabupaten Aceh Timur tersebut.

Bahkan dari komunikasi yang terjalin antara ulama dengan polisi melahirkan beberapa kebijakan-kebijakan yang sangat baik dalam menghapus kemungkaran di Aceh Timur. Ada beberapa program yang terjalin atas diskusi antara ulama dengan polisi, antara 
lain program "saweu pesantren", yang dalam hal ini dari pihak kepolisian mengunjungi dan bersilaturrahmi ke dayah ataupun pesantren yang ada di Kabupaten Aceh Timur. Program pembinaan masyarakat yang ada di Lembaga Pemasyarakatan, polisi dalam hal ini selalu menggandeng para ulama, biasanya ulama dayah untuk memberikan tausyiah kepada masyarakat disana, dan program ini mendapat tanggapan yang baik dari masyarakat, walaupun pada awalnya dari mereka ada sebagian yang tidak menerima dakwah ataupun nasehat yang diberikan ulama dayah tersebut

Sedangkan tantangan komunikasi antara ulama dengan polisi dalam menanggulangi kemungkaran di Kabupaten Aceh Timur adalah menciptakan komunikasi dengan penerapan syariat Islam secara kaffah. Apabila penerapan syariat Islam ini sudah ditegakkan secara kaffah, maka insya Allah segala bentuk kemungkaran yang ada di Kabupaten Aceh Timur akan tidak ada lagi.

Dalam Undang-Undang No 11 tahun 2006 tentang Pemerintahan Aceh termaktub di dalamnya tentang keistimewaan Daerah Aceh dengan pemberlakuan Syariat Islam yang terdapat dalam Bab 27 Pasal 125- 127. Dalam Pasal 126 (1) disebutkan bahwa "Setiap pemeluk agama Islam di Aceh wajib menaati dan mengamalkan Syariat Islam”, Pasal 126 (2) "Setiap orang yang bertempat tinggal atau berada di Aceh wajib menghormati pelaksanaan Syariat Islam".

Penerapan syariat Islam yang kaffah adalah tanggung jawab pemerintah (WH) dan masyarakat umumnya, namun pada dasarnya tanggung jawab itu secara utuh juga dipikul oleh kepala keluarga. Lingkungan pertama itu adalah keluarga, kepala keluarga sebagai nakhoda dalam sebuah rumah tangga bertanggung jawab untuk memberikan pemahaman tentang Islam yang lengkap dan benar kepada seluruh anggota keluarga.

Keimanan dengan keinginan menerapkan Syariat Islam semata belum cukup seandainya tidak memperhatikan berbagai aspek lain yang memiliki hubungan dan korelasi dengan pelaksanaan Syariat Islam tersebut. Aspek lain adalah keyakinan dan perkembangan pemikiran yang berkembang dalam masyarakat modern dimana penganutnya bukan hanya kalangan Islam namun juga masyarakat secara keseluruhan. Untuk menjaga kehidupan yang harmonis dan berjalan dengan baik dan tenang, maka apa saja yang dilakukan oleh sekelompok orang harus memperhatikan aspek keseluruhan yang lebih luas.

Komunikasi organisasi yang terjadi dalam suatu organisasi antara ulama dan kepolisaian berlangsung dalam suatu jaringan yang lebih besar dari pada komunikasi 
kelompok. Komunikasi organisasi seringkali juga melibatkan komunikasi secara sosialisasi dan mediasi.

Gambar komunikasi :

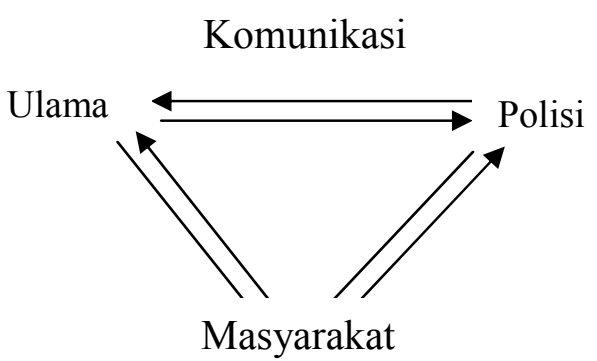

\section{G. Penutup}

Berdasarkan hasil penelitian dan pembahasan yang dilakukan, penulis dapat menarik kesimpulan mengenai Komunikasi Antara Ulama Dayah dan Kepolisian dalam Menanggulangi Kemungkaran di Kabupaten Aceh Timur adalah : berdasarkan data yang ada dapat diklasifikasikan bahwa terdapat tiga jenis kemungkaran yang sering terjadi di wilayah Kabupaten Aceh Timur yaitu pencurian, narkoba dan aliran sesat.

Adapun bentuk-bentuk komunikasi organisasi ulama dan kepolisian antara lain

1. Sosialisasi ulama dengan kepolisian dalam bentuk pertemuan di dayah, aula kantor kecamatan yang ada di Kabupaten Aceh Timur dan di aula Kapolres.

2. Mediasi ulama dan kepolisian dengan cara mengunakan alat-alat media untuk saling berkomunikasi dan saling menginformasi agar informasi tersebut bisa mudah didapatkan dan bisa diatasi dengan secepatnya.

Berdasarkan uraian di atas dapat diketahui bahwa komunikasi ulama dayah dengan kepolisian selama ini berjalan dengan baik.

Pada bagian ini penulis mencoba mengajukan beberapa saran yang berhubungan dengan komunikasi antara ulama dayah dengan kepolisian dalam menaggulangi kemungkaran sebagai sumbangan pikiran dari penulis. Adapun saran tersebut adalah sebagai berikut :

1. Berdasarkan hasil penelitian, komunikasi antara ulama dayah dengan kepolisian dalam menaggulangi kemungkaran dilihat dari indikator pertemuan dan kerja sama pada Kapolres Kabupaten Aceh Timur memiliki komunikasi cukup besar. Hasil ini menunjukkan bahwa komunikasi ulama dengan kepolisian sudah cukup maksimal, 
maka dalam hal ini harus lebih ditingkatkan sehingga komunikasi yang disampaikan dapat berpengaruh positif dan lebih diterima sehingga menimbulkan umpan balik yang mampu memberikan motivasi dan semangat baik terhadap ulama maupun kepolisian dalam melaksanakan tugas-tugas dan tanggung jawabnya.

2. Melalui komunikasi antara ulama dengan kepolisian yang baik diharapkan dapat menimbulkan rasa tanggung jawab agar tugas-tugas yang dilaksanakan dapat mencapai tujuan sebagaimana yang diharapkan. Selain itu pihak kepolisian berusaha mengikut sertakan para ulama untuk turut berpartisipasi dalam menyumbangkan ide dan pemikirannya, sehingga para ulama ikut terlibat dan bertanggung jawab atas tertegahnya kemungkaran. Dengan demikian ulama akan merasa dihargai keberadaannya dalam masyarakat. Komunikasi antara ulama dan kepolisian yang berjalan baik dalam penyampain pesan diharapkan akan dapat meningkatkan komunikasi yang efektif.

Diharapkan dengan saran ini dapat memberikan masukan yang bermanfaat bagi ulama dan kepolisian Kabupaten Aceh Timur dalam melaksanakan komunikasi untuk mencegah kemungkaran di Kabupaten Aceh Timur. 


\section{DAFTAR PUSTAKA}

Deddy Mulyana, , Ilmu Komunikasi, Bandung: Remaja Rosdakarya. 2010

H. Anwar Arifin, Ilmu Komunikasi, Jakarta: Raja Grafindo Persada, 2006

Onong Uchjana Efendy,. Ilmu, Teori dan Filsafat Komunikasi. Bandung: Citra Aditya Bakti 2003 